\title{
IMPACT OF ORGANIZATIONAL COMMITMENT ON EMPLOYEE JOB PERFORMANCE-A STUDY IN BANKING SECTOR.
}

\author{
Dr K. Sunanda \\ Associate professor
}

\begin{abstract}
Organization which have clear mission, goals and objective with good infrastructure still need human resources inside them to operate every activities in order gain organizational mission. Organizations have to manage human resources effectively and must continually train and develop them. Based on resource based view theory, human resources in organization often seen as an asset, not just as capital. Improving and sustaining high performance of the employees is critical to organizational success .This study investigates the relationship between organizational commitment and employees' job performance in Banks. In the comparative analysis of three dimensions of organizational commitment, normative commitment has a positive and significant correlation with employees' job performance. The results revealed a positive relationship between organizational commitment and employees' job performance.

. Keywords: Organization commitment, Job performance.
\end{abstract}

\section{INTRODUCTION}

The study of employee's job performance and organizational commitment is of foremost importance to the top-level management of the organizations. Somers \& Birnbaum (1998) ${ }^{1}$ studied the relationship of career commitment to performance effectiveness and resulted in a positive relationship. Job satisfaction is not the single dependent variable of commitment; it has numerous other outcomes in the organizations.

oliven (2009) ${ }^{2}$ defines Commitment has always been believed as the driving force behind a person's success. A person who has committed himself to a task will pursue it until its completion even if he experience obstacles during the process. It is his commitment that will drive him to rise above the challenges.

Robbins, (2001) ${ }^{3}$. Organizational commitment is defined as "a state in which the employee identifies with a particular organization and its goals, and wishes to maintain membership in the organization.

Newstrom (2007) ${ }^{4}$ calls it employee loyalty. Schultz and Schultz (2002) ${ }^{\mathbf{5}}$ say it is manifested in the employees' acceptance of organizational values and goals and his loyalty to the organization reflected by his continual desire to remain in the organization.

According to Meyer and Allen (1990) ${ }^{6}$ of organizational commitment suggest three types of organizational commitment that are, affective commitment which measures an employee's emotional attachment to, identification with, and involvement in the organization, normative commitment reflects pressures on an employee to remain with an organization resulting from organizational obligations. Continuance commitment refers commitment associated with the costs that employees perceive are related to leaving the organization.

Chusmir (1984) ${ }^{6}$ Organizational commitment has same impact on women as it is on men, but for some instances women react differently. Connectivity of colleagues and the style of management can enhance commitment of employees and are considered as an important asset of the company (Nijhof, de jong, and Beukhof 1998) ${ }^{7}$. Commitment of employees can be an important instrument for improving the performance of the organizations. In most of the organizations the 
high rate of stress leads to lower satisfaction and in turn produces very low organizational commitment (Elangovan 2001).

\section{LITERATURE REVIEW}

Shore, Barksdale \& Shore $(1995)^{9}$ studied 231 managers and 339 subordinates in multinational firms in United States and found that affective commitment and job performance are positively correlated.

Somers \& Birnbanm, $(1998)^{10}$ studied the relationship of work related commitment and input on employee job performance, however their findings suggested that career commitment is positively related to job performance but no relationship existed between organizational commitment and job performance. Both affective and normative commitments were found unrelated to job performance. Lee $\boldsymbol{\&}$ olshfski, $(2002)^{11}$ studied the behavior of organizational commitment of the firefighters in New York and their study led to believe that organizational commitment offers considerable promise in describing the positive behaviors. Furthermore, Individuals take jobs, they identify with the role attached to the job, they become committed to doing the job, and they behave according to the expectations attached to that job.

Suliman \& Lles, (2002) $)^{12}$ explored the nature of organizational commitment in three industrial units in Jordan by using employees' job performance and five demographic variables. Their research revealed that that organizational commitment comprises three-dimensional concept. The findings also uncovered a positive relationship between commitment (all the three components) and job performance. Moreover, organizational commitment and its three dimensions present positive and negative relationships with age, sex, education, job status, and organizational tenure variables.

Chen, Silverthrone and Hung, (2006) ${ }^{13}$ studied the relationship of the organizational commitment, communication and job performance. Their research findings indicated that there are positive relationships between organizational communication, organizational commitment and job performance. This finding suggested that companies strengthen their communication channels and processes in order to strength their accounting professionals' organizational commitment and job performance.

Clarke, (2006) ${ }^{14}$ studied the commitment and network performance in UK based health care units and found that commitment play a significant role specifically with performance outcomes. The researcher found that statistically both affective and normative forms of commitment have significant impact on performance. Affective commitment was positively related to network performance. The finding that continuance commitment was negatively related to network performance suggests that the relationship between commitment and performance within networks is not direct. The above literature review reveals that there is some definite relationship exists between organizational commitment and employee's job performance.

\section{OBJECTIVES OF THE STUDY}

1. To study the importance of organizational commitment in the organizations

2. To investigate the relationship between organizational commitment and employees job performance i.e., Affective, Normative and Continuous commitment and employees job performance.

\section{LIMITATIONS OF THE STUDY}

1. The findings of the study are completely based on responses of the sample respondents. 
2. The study is limited to the select organization for the study.

\section{HYPOTHESIS}

H1: There is a positive relationship between organizational commitment and employee's job performance

H1a: Affective commitment is positively and significantly related to employee's job performance

H1b: Continuance commitment is positively and significantly related to employee's job performance

H1c: Normative commitment is positively and significantly related to employee's job performance

\section{RESEARCH METHODOLOGY}

The research study includes data collection from primary and secondary data sources. Primary data collection is with the help of questionnaire consists of likert's scale ranging from zero to five $(0=$ Never, $5=$ often $)$ which include questions on organizational commitment and job performance. Secondary data sources are from articles, Journals and Websites.

By using likert's scale ranging from zero to five $(0=$ Never, $5=$ Often $)$, the instrument was developed which combined portions of existing surveys related to organizational commitment, and job performance.

\section{VARIABLES FOR THE STUDY}

The variables under study are organizational commitment as independent variable and employee's job performance as dependent variable. Commitment is further disintegrated into three parts affective, normative and continuance. Meyer and Allen (1990) defined commitment as the employee's feelings of obligation to stay with the organization: feelings resulting from the internalization of normative pressure exerted on an individual prior to or following entry. While the job performance of employees has been defined as work performance in terms of quantity and quality expected from each employee.

\section{Reliability statistics}

Organizational commitment is a condition in which a person siding company employees as well as the goals and desires to retain membership in the company. According to Allen and Meyer developed a three-component model to test commitment among employees. An organizational commitment scale which adapted from Allen and Meyer in this study, which contains three dimensions as follows: affective commitment, continuance commitment, and normative commitment. Reliability of this construct which shown from Cronbach alpha value was found about 0.816 .

Job performance is the ability of a person in the execution of his duties with the motivation to get maximum work. A job performance scale used in this study which adapted from Pearce and Porter contains four dimensions as follows: quality of performance, quantity of performance, completing tasks on time, cooperative working with others. Reliability of this construct which shown from Cronbach alpha value was found about 0.725 . 


\section{DATA ANALYSIS}

The data was analyzed by using SPSS software. Percentage, Frequencies and Mean values are found. Further regression analysis was done to know the impact of Organizational commitment on Job performance.

\section{Interpretation of the data}

This section presents the demographic profiles of the respondents. Of the respondents, 35 (53.80\%) were male, while $30(46.20 \%)$ were female. In terms of age, 20-25 yrs 8 respondents (12.30\%), 26- 30 yrs 13respondents (20\%), 31- 35 year 26 respondents (45\%), while 36-40 year 18 respondents $(27.70 \%)$. In terms of years of work tenure, 1-3 yrs 14 respondents (21.50\%),36yrs 22 respondents(33.80\% ),6-9yrs 15 respondents(23.10\%) and >9 yrs consisted 14 respondents $(21.50 \%)$.

Table 1 Demographic Profile of respondents

\begin{tabular}{|l|l|l|l|}
\hline Demographics & Categories & Frequency & \% \\
\hline \multirow{4}{*}{ Agender } & Male & 35 & 53.80 \\
\cline { 2 - 4 } & Female & 30 & 46.20 \\
\cline { 2 - 4 } & $20-25$ & 8 & 12.30 \\
\cline { 2 - 4 } & $26-30 \mathrm{yrs}$ & 13 & 20.00 \\
\cline { 2 - 4 } & $31-35 \mathrm{yrs}$ & 26 & 40.00 \\
\cline { 2 - 4 } & $36-40 \mathrm{yrs}$ & 18 & 27.70 \\
\hline \multirow{5}{*}{ Work tenure } & $1-3 \mathrm{yrs}$ & 14 & 21.50 \\
\cline { 2 - 4 } & $3-6 \mathrm{yrs}$ & 22 & 33.80 \\
\cline { 2 - 4 } & $6-9 \mathrm{yrs}$ & 15 & 23.10 \\
\cline { 2 - 4 } & $>9 \mathrm{yrs}$ & 14 & 21.50 \\
\hline
\end{tabular}

Table2. Mean values of the Dimensions

\begin{tabular}{|l|l|l|l|}
\hline Variables & Dimensions & Mean & Std dev \\
\hline \multirow{3}{*}{$\begin{array}{l}\text { Organizational } \\
\text { commitment }\end{array}$} & Affirmative commitment & 3.80 & .755 \\
\cline { 2 - 4 } & Continuance commitment & 4.02 & .602 \\
\cline { 2 - 4 } & Normative commitment & 3.94 & .731 \\
\hline \multirow{5}{*}{ Job performance } & Work quality & 3.78 & .654 \\
\cline { 2 - 4 } & Quantity of work & 3.75 & .733 \\
\cline { 2 - 4 } & Duration of work completion & 3.95 & .712 \\
\cline { 2 - 4 } & Work cooperation & 3.97 & .621 \\
\hline
\end{tabular}

Table 2 summarizes the Mean values of the variables for organization commitment i.e, affirmative commitment(3.80), Continuance commitment (4.02)and Normative commitment(3.94) and Job performance variables work quality(3.78), Quantity of work(3.75), Duration of work completion(3.95) and Work cooperation(3.97).

Table 3 Regression analysis table

\begin{tabular}{|l|l|l|l|}
\hline Variables & Beta value & t static & Sig \\
\hline Constant & 1.56 & 4.486 & 0.00 \\
\hline Organizational commitment & 0.218 & 5.387 & 0.00 \\
\hline Affirmative commitment & 0.219 & 2.721 & 0.07 \\
\hline
\end{tabular}




\begin{tabular}{|l|l|l|l|}
\hline Continuance commitment & 0.287 & 3.607 & 0.00 \\
\hline Normative commitment & 0.321 & 4.162 & 0.00 \\
\hline
\end{tabular}

Dependent variable Job performance

Table 3 presents the regression coefficient of Independent variable (i.e) Organizational commitment and its dimensions on dependent variable Job performance. The regression analysis accounted for $13 \%$ variance in Job performance. All the three dimensions have impact on job performance. On further analysis, out of three dimensions of organizational commitment, normative commitment has positive and significant relationship on employees' performance.

\section{CONCLUSION}

The purpose of the current study was to examine the relationship between Organizational commitments on Employee job performance in Banks. The dimensions of Organizational commitment Affirmative, Continuance and Normative commitment has significant impact on the dimensions of Job performance i.e., Quality of work, Quantity of work, Duration of work completed and Work cooperation among the employee in Banks. The Organization has to concentrate on the variables of organization commitment factors so that they can increase the employee's job performance

\section{References}

I. Mark john Somer \&Dee Birnbaum (1998) "Work-related commitment and job performance: it's also the nature of the performance that counts", Journal of organization behaviour,Vol 19,issue 6,pp621-634.

II. Robbins, S. (1998). Organizational Behavior: Contexts, Controversies, Applications; Prentice- Hall, USA. Page 142

III. Newstrom, J.W., \& Davis, K. (1997). Organizational Behavior: Human Behavior at Work, 10th ed., McGraw-Hill, New York, NY.

IV. Schultz, D.P, Schultz S. E. (2010). Psychology and Work today: An introduction to industrial and organisational psychology. 10 th edition.

V. Meyer, J. \& Allen, N. (1991). A three-component conceptualization of organizational commitment. Human Resources Management Review, 1(1), 81-89.

VI. Leonard H.ChusmirAn integrative process model of organizational commitment for working women and men, Journal of business and psychology vol 3 pp 88-104.

VII. Nijhof, J.W., de Jong, M.J. and Beukhof, G. (1998) Employee Commitment in Changing Organisations: An Exploration. Journal of European Industrial Training, 22, 243-248.

VIII. A.R. Elangovan, Causal ordering of stress, satisfaction and commitment, and intention to quit: a structural equations analysis, Leadership \& Organization Development Journal, 2001, 22(4), 159-165

IX. Lynn McFarlane Shore, Kevin Barksdale, Ted H. Shore (1995), Managerial Perceptions of Employee Commitment to the Organization, The Academy of Management Journal,38 (6)1593-1615

X. Seok-Hwan\& Dorothy olshfski (2002)An Examination of Variations in the Nature of Employee Commitment: Tissue1he Case of Paid and Volunteer Firefighters, International review of public administration, $\mathrm{Vol} 7$ 
XI. Suliman, A.M.T. and Iles, P. (2002) Is Continuance Commitment Beneficial to Organizations? Commitment-Performance Relationship: A New Look. Journal of Managerial Psychology.

XII. Chen, J.C., Silverthorne, C. and Hung, J.Y. (2006) Organization Communication, Job Stress, Organizational Commitment, and Job Performance of Accounting Professionals in Taiwan and America. Leadership \& Organization Develop- ment Journal, 27, 242-249.

XIII. Clarke. N (2006), The relationships between network commitment, its antecedents and network performance, Management Decision, 44 (9), 1183-1205

XIV. Colquitt, Jason A, Jeffery A Lepine, Michael J Wesson. Organizational Behavior : Improving Performance and Commitment in The Workplace. McGraw - Hill / Irwin, 2009.

XV. Robbins, Stephen. Organizational Behaviour 12e. Prentice Hall, 2007.

XVI. Mathis, L Robert and Jackson H. John. Human Resource Management, Ninth Edition, USA: South Western College Publishing, 2007.

XVII. Sekhar, Chandra, Manoj Patwardhan, Rohit Kr. Singh. A literature review on motivation. Glob Bus Perspect, 2013, 1:471-487.

XVIII. Spector, P. E. Job satisfaction: Application, assessment, causes, and consequences. Thousand Oaks, CA: Sage, 1997. The Impact Of Organizational Commitment, Motivation and Job Satisfaction On .... DOI: 10.9790/487X-18224150 www.iosrjournals.org 50| Page

XIX. Moorhead, G. \& Griffin, R.W. Organizational behavior: Managing people and organizations (5111 ed ). Boston, MA: Houghton Mifflin, 1998.

XX. Meyers, S. Who are your motivated workers? Harvard Business Review January/February, 1-16, 1964.

XXI. Maslow, A. A theory of human motivation. Psychological Review, 50(4), 1943, 370-96.

XXII. Herzberg, F., Mausner, B., \& Snyderman, B. The motivation to work. New York, NY: John Wiley \& Sons, 1959.

XXIII. Dharmanegara. I.B.A., Made Sudarma, Noermijati, Solimun. Effect of Spiritual Intelligence and Asta Brata Leadership to the Culture of Tri Hita Karana and Employment Performance. IOSR Journal of Business and management 2013 vol.11-issue 2 ,

XXIV. Allen, N.J., J.P. Meyer. The Measurement and Antecedents of Affective, Continuance, and Normative Commitment to the organization. Journal of Occupational Psychology Volume 63, Issue 1, pages 1-18, March 1990.

XXV. Bateman, T. S., \& Strasser, S. A longitudinal analysis of the antecedents of organizational commitment. Academy of Management Journal, 27, 1984, 95-112.

XXVI. Markovits Yannis, Davis Ann J.,Dick Rolf van. "Organizational Commitment Profiles and Job Satisfaction among Greek Private and Public Sector Employees", International Journal of Cross Cultural Management, Vol. 7(1), 2007.

XXVII. Elangovan, A.R. Causal Ordering of Stress, Satisfaction and Commitment, And Intention to Quit : A Structural Equation Analysis. Leadership and Organization Development Journal, 2001, Vol. 22 No. 4 pp $159-165$.

XXVIII. Tobing, Diana Sulianti K.L. Pengaruh Komitmen Organisasional dan Kepuasan Kerja Terhadap Kinerja Karyawan PT. Perkebunan Nusantara III di Sumatera Utara. Jurnal Manajemen dan Kewirausahaan, Vol. 11, No. 1, Maret 2009 : 31 - 37.

XXIX. Lawler, E. E. Motivation in work organizations. San Francisco: Jossey-Bass, 1994. 
XXX. Tietjen, Mark A. and Robert M. Myers. Motivation and job satisfaction. Management Decision 36/4 [1998] 226-231.

XXXI. Lee, Hung-Wen, CHing-Hsiang Liu. The Relationship Among Achievement Motivation, Psychological Contract and Work Attitudes. Social Behavior and Personality, 2009 Vol 37 (3), pp $321-328$.

XXXII. Orpen, Christopher. The effects of formal mentoring on employee work motivation, organizational commitment and job performance. The Learning Organization Volume 4 . Number $2 \cdot 1997 \cdot$ pp. 53-60.

XXXIII. Perry, James L., and Lois R . Wise. The Motivational Bases of Public Service . Public Administration Review 50 ( 3 ) : 367 - 73, 1990.

XXXIV. Alonso, Pablo, Gregory B. Lewis. Public Service Motivation and Job Performance : Evidence from the Federal Sector. The American Review of Public Administration 2001 31: 363.

XXXV. Ajzen, Icek. Job Satisfaction, Effort, and Performance: A Reasoned Action Perspective. Contemporary Economics Vol. 5 Issue 4 32-43, 2011.

XXXVI. Koesmono, Teman. Pengaruh Budaya Organisasi Terhadap Motivasi Dan Kepuasan Kerja Serta Kinerja Karyawan Pada Sub Sektor Industri Pengolahan Kayu Skala Menengah Di Jawa Timur. Jurusan Ekonomi Manajemen, Fakultas Ekonomi Universitas Kristen Petra. http://puslit.petra.ac.id/ puslit/journals/. , 2005.

XXXVII. [24]. Arshadi, Nasrin. Basic need satisfaction, work motivation, and job performance in an industrial company in Iran. Procedia Social and Behavioral Sciences 5 (2010) 12671272.

XXXVIII. [25]. Shore, Lynn M and Harry J. Martin. Job Satisfaction and Organizational Commitment in Relation to Work Performance and Turnover Intentions. Human Relations Volume 42 Number 7, 1989, pp. 625 - 638.

XXXIX. [26]. Saari, Lisa M., Timothy A. Judge. Employee attitudes and job satisfaction. Human Resource Management, Winter 2004, Vol. 43, No. 4, Pp. 395-407.

XL. [27]. Iaffaldano, Michelle T. and Paul M. Muchinsky. Job Satisfaction And Job Performance : A Meta Analysis. American Psychological Association : Psychological Bulletin Vol. 97, No 2. pp 251 - 273, 1985.

XLI. [28]. Ostroff, Cheri. The relationship between satisfaction, attitudes, and performance: an organizational level analysis. Journal Of Applied Psychology (JAP) 1992, 77, 963 - 74.

XLII. [29]. Yousef, Darwish A. Organizational Commitment as Mediator of The Relationship berween Islamic Work Ethiccs and Attitudes toward Organizational Change. Human Relations, 2000, Vol. 53 (4): 513-537.

XLIII. [30]. Benkhoff, Birgit. Ignoring Commitment Is Costly: New Approaches Establish the Missing Link Between Commitment and Performance. Human Relations 1997, 50: 701.

XLIV. [31]. Suliman, Abubakr dan Paul Iles. Is continuance commitment beneficial to organizations? Commitment-performance relationship: a new look. Journal of Managerial Psychology, 2000, Vol. 15 No. 5, pp. 407-426.

XLV. [32]. Suliman, Abubakr M.T. Is it really mediating construct? The Mediating Role of Organizational Commitment in Work Climate - Performance Relationship. Journal of Management Development, 2002, Vol.21 No.3, pp. 170-183.

XLVI. [33]. Allen, Natalie J., John P. Meyer. A Three Component Conceptualization of Organizational Commitment.Human Resource Management Review, 1991, Vol 1 No 1 pp $61-89$. 
XLVII. [34]. McClelland, D.C. Measuring motivation in phantasy: The achievement motive. In H. Guetzkow (Ed.), Groups, leadership, and men (pp. 191-205). New York: Russell \& Russell, 1963.

XLVIII. [35]. Locke, E. A. What is job satisfaction? Organizational Behavior and Human Performance, 4, 1969, 309-336.

XLIX. [36]. Pearce, J., \& Porter, L. Employee Responses to Formal Performance Appraisal Feedback. Journal of Applied Psychology, 1986, 71 (2): 211-218. 